\title{
The legitimacy of European Union foreign policy
}

Helene Sjursen is Research Professor at ARENA Centre for European Studies, at the University of Oslo

Published: "The legitimacy of European Union foreign policy", Global Affairs, 2018, $\underline{10.1080 / 23340460.2018 .1532308}$

\begin{abstract}
In this article I enquire into the sources of legitimacy of the European Union's (EU) Common Foreign and Security Policy. I suggest that as the EU has moved beyond intergovernmentalism in this policy field, it cannot derive its legitimacy solely from the national systems of the member states. It must establish an additional channel of legitimacy, which is derived directly from the EU. Challenging the conventional position on the legitimacy of global governance institutions, I further suggest that EU institutions can only make a reasonable claim to prevail over the member states in this policy field if they contribute to enhance the normative status of the foreign policy. That the cooperative endeavour is mutually beneficial is not a sufficient basis for the legitimacy of EU foreign policy. Drawing on a deliberative perspective, I suggest that we may expect to find two mutually reinforcing sources of legitimacy at the EU level. However, these would mainly contribute to enhance the external legitimacy of the CFPS. Paradoxically, they may at the same time constrain the internal legitimacy of the EU's foreign policy.
\end{abstract}

\section{Keywords}

European Union, Common Foreign and Security Policy (CFSP), Legitimacy, Democracy, Foreign Policy 


\section{Introduction $^{1}$}

In this article, I enquire into the sources of legitimacy of the European Union's (EU) Common Foreign and Security Policy (CFSP). The question of the EU's legitimacy has been addressed in a number of scholarly works. Some have with Joseph Weiler (1999) supported the view that the EU's legitimacy is derivative of the member states, that is, it is dependent on the democratic legitimacy of the member states. Others have questioned if such a legitimacy basis is sufficient, and argued that as European integration has moved beyond the nation state, it requires an autonomous legitimacy basis. This latter point has led to a series of analyses of what would be the legitimacy basis of a polity that is neither a state nor an international organization (Eriksen 2009, Neyer 2012, Scharpf 1999, Schmidt 2013).

This debate has had surprisingly little effect on scholarly analyses of the EU's foreign and security policy. No doubt due to the intergovernmental character of the EU's foreign and security policy, the question was long considered to be of little relevance. However, in recent years, scholars have demonstrated that European foreign policy making is increasingly constructed and pursued through shared policy-making structures in Brussels. Against this backdrop it is pertinent to ask what might be the legitimacy basis also of the Union's foreign and security policy.

Legitimacy is a value in itself. However, it is also a precondition for the stability of a political order. The EU's foreign policy, which is subject to a series of conflicting and contrasting interests and values, faces particular challenges in this regard. This is so as EU policy makers do not have the formal authority to subject member states to collective decisions. Member states must on a voluntary basis support EU policies and comply with collective decisions.

The aim of this article is to discuss how we might conceive of the legitimacy of the CFSP as well as to tease out what might be sources of legitimacy, given the particular characteristics of this foreign policy system. The purpose is not to (empirically) establish the actual legitimacy of the EU's foreign and security policy. Drawing on a deliberative perspective, I suggest that we may expect to find some sources of legitimacy at the EU level. However, these would mainly contribute to enhance the external legitimacy of CFSP. Paradoxically, they may at the same time constrain the internal legitimacy of the EU's foreign policy.

${ }^{1}$ This article is part of the research project "The Legitimacy of the EU Foreign and Security Policy in the Age of Global Contestation" (LEGOF), financed by the Norwegian Research Council. I should like to thank Erik O. Eriksen and Johanne Døhlie Saltnes for comments on an earlier draft of the article. 


\section{What legitimacy requirements for EU foreign policy?}

The answer to the question of how to draw stable support for the EU's foreign and security policy is not self-evident. To some, establishing such support would be a matter of incentives. However, in the domain of foreign and particular security and defence policy, the incentives have been limited. There are several reasons for this. NATO has guaranteed Europe's security. Some have therefore seen European initiatives in this domain as unnecessary, and perhaps also in conflict with the US/NATO interests. Moreover the importance of sovereignty underlined by the UN is usually expected to make states particularly skeptical to European integration in this field. EU foreign policy is "high politics", which raises questions of territorial control and of who has ultimate control over the instruments of violence. Consequently, classical realists (Hoffmann 1966, Menon 2013), structural realists (Hyde-Price 2006) and rational institutionalists (Gegout 2010) have converged in predicting that support for "co-operation in the second pillar will remain limited to a set of 'second order' concerns agreed on the basis of the lowest common denominator" (Hyde-Price 2006, p. 231).

In the current global context, characterized by a return to geopolitical competition, by a more unpredictable United States as well as an increasingly confrontational Russia, the incentives for integration may have changed. The demands for a strengthening of the EU's military capabilities, as well as for Europe to focus more on hard power rather than soft power have increased. And, the EU has in fact taken several initiatives to strengthen its capabilities in security and defence, most notably through the Permanent Structured Cooperation (PESCO).

However, incentives are not objective facts, they are subject to interpretative frames. Often, member states define and perceive changes in global politics differently. The incentives for integration may have intensified for some, and not for others.

Regardless of whether or not the EU is to transform itself into a military power, or sustain its role as a vanguard of the liberal order, the EU must sustain its legitimacy basis, taking into account the complexity of global transformations. The question of legitimacy is an end in itself. However, it is also a precondition for stability. Capabilities are needed, but what are they good for? For what purpose, for whose use, for which interests and values are they needed? In mobilizing support and in drawing up agreements, such questions of legitimation must be responded to. This is even more of a challenge as global transformations are complex and multifaceted. The apparent rise of geopolitics and of great power competition coexists with the perpetuation of global governance regimes and the recognition of a need for cooperation on solving common problems. But what kind of legitimacy would be required with regard to the CFSP?

In national, single state political systems, democracy is seen as an indispensable presupposition for the legitimacy of political order. In modern states, it is assumed that citizens should be able to govern themselves through law and politics. Legitimacy is framed in normative terms, as democratic legitimacy (Dworkin 1986, Habermas 1996, 
Rawls 1993, Sen 2010). We expect a democratic order to be in line with the requirements of autonomy and accountability (Eriksen 2009). There must be procedures in place that make it possible for those affected by laws to also be the authors of the laws that they are expected to abide by. It must be possible for citizens to hold those in power responsible for the decisions that they make. These requirements, which are an explicit part of Habermas' discourse theoretical model of deliberative democracy (Habermas 1996), are identifiable in most theories, and may thus be seen to constitute a "democratic minimum" (Eriksen 2009; cp. Dahl 1989; Rawls 1993; Pettit 1997).

However, the EU is not a state. The EU institutions cannot impose anything on the member states or sanction them if they do not comply with joint decisions. While the core requirements of autonomy and accountability appear unchallenged in debates about democracy, there is disagreement regarding the extent to which the requirements of democratic institutions in transnational, multilevel political orders such as the European Union should be adapted (Eriksen 2005). As noted in the introduction, scholars debate both the extent to which such adaptations are required, and what would be normatively adequate institutional adaptations (Eriksen 2009, Neyer 2012, Scharpf 1999, Schmidt 2013, Weiler 1999). Without entering into the details of this debate, we might say that amongst those favouring an adaption of institutional requirements, there is a shift from classical models of representative democracy to concepts of functional or segmented representation, which is "...often garnished with some notion of deliberation" (Peters 2005, p. 111). This debate is also relevant to EU foreign policy.

\section{The nature of the polity}

Formally the EU's foreign policy is intergovernmental. We could thus assume with Weiler (1999) that its legitimacy would be derivative of the member states. However, policy making in the field of foreign and security is increasingly constructed and pursued through new and shared policymaking structures in Brussels (Allen 1998, Sjursen 2011, Smith 2004, Tonra 2003, Vanhoonacker, Dijkstra \& Maurer 2010). The decisions made at the EU level bind the governments of the member states. We cannot assume that these decisions always allow every member state to more effectively pursue nationally defined goals, as we usually do in intergovernmental organizations (Sjursen 2011). The foreign policy goals of the member states may even be redefined or altered altogether, through joint decision-making within the EU's institutions. The decisions made jointly by member states also affect citizens. Public funds may be required to pay for the realization of decisions, and young men and women may be required to contribute to military action. Changes such as these make it difficult for the EU to rely solely on the member states as a source of legitimacy of its foreign policy. The collectivity of member states de facto take certain decisions that may have direct consequences for individual states and their citizens. As a result, this collectivity (or polity) may require an independent legitimacy basis. 
The uncertainty with regard to what might be the legitimacy basis of the EU's foreign policy is further reinforced due to the specific nature of foreign policy itself. Some argue, with John Locke, that foreign policy making should essentially be left to the executive and not be constrained by too much interference from the elected representatives of citizens. ${ }^{2}$ Foreign policy is different from domestic politics. Law making is less central, and the ultimate aim is commonly considered to be the protection of the "interests of the state" in the face of external threats. According to Thym, this "structural difference" suggests that we should not expect foreign policy to be subjected to the same kind of scrutiny as domestic political issues (Thym 2006).

However, it is difficult to find any principled arguments not to subject foreign policy to democratic control. Policy-making in this field requires normative choices and prioritisations, not just factual expertise. Policy makers' choices have implications for the distribution amongst citizens (and in the case of the EU amongst states) of good, burdens and risks. They affect how much time young men and women must spend as conscripts, as well as how much of public funds should be spent on defence compared to other issues of public interest. There may be particular instances or issues that require confidentiality. However as long as there is agreement on what those issues are, and what procedures should be applied to handle them, they do not constitute a reason for leaving the entire portfolio of foreign policy exclusively in the hands of the executive.

While the nature of foreign policy does not warrant its exemption from democratic scrutiny, it does raise some challenges that are different from those in domestic politics. Foreign policy affects the interests of states and citizens across the world. Arguably this puts an additional legitimacy requirement on foreign policy. It requires both internal and external legitimacy. To be sure, in the age of globalization, this is also the case with many parts of domestic politics. However, this only serves to reinforce the point that it may be difficult to conceive of foreign policy as legitimate unless it takes on board the interests and values of those outside its borders.

Drawing on a normative conception, and bearing in mind its ambiguous status as neither intergovernmental nor supranational, I suggest that the legitimacy of EU foreign policy cannot be derived from the political systems of the member states alone. In order for the EU to be able to make a reasonable claim to prevail over the member states, as well as for the EU to be listened to by third parties, it must draw on additional sources of legitimacy that are independent of the individual member states. What, if any, might these additional sources be?

\footnotetext{
${ }^{2}$ For an explication of Locke's position on democracy and foreign policy, see Michael W. Doyle Ways of War and Peace (1997), pp. 2019-220.
} 


\section{Two mutually reinforcing sources of legitimacy}

As already noted, policy making in this field is increasingly constructed and pursued through new and shared structures in Brussels (Smith 2004). The term "Brusselisation" of European foreign and security policy (Allen 1998) depicts the shift in the locus of decision-making to Brussels-based institutional structures (Sjursen 2011). In spite of formally safeguarding the sovereign right of member states to veto any decision that they disagree with, decision-making competence is creeping to Brussels. EU level institutions, most importantly the European External Action Service (EEAS) and the EU delegations in third countries support joint decision-making at the EU level. The expertise provided by the EEAS is supplemented by that of the European Commission, which is also increasingly encroaching on the domain of CFSP (Strikwerda 2016). Experts in the Commission and the EEAS provide a common knowledge base that informs policymaking, and that adds to the expertise provided by the relevant ministries in the member states (Bicchi 2011). ${ }^{3}$ Within these shared institutional structures, member states are authorized by the Treaty to make collective decisions on all aspects of foreign and security policy.

The Brussels-based institutions are seen to gain the advantage compared to national foreign ministries due amongst other things to easy and daily access to information and dialogue with partner states (Christiansen and Vanhoonacker 2008, Duke and Vanhoonacker 2006, Howorth 2010, Juncos and Pomorska 2011, Juncos and Reynolds 2007, Tonra 2003, Vanhoonacker et al. 2010). Since the establishment of European Political Cooperation in the late 1960s, member state interaction has moved from irregular ad hoc discussions to a densely institutionalized system of foreign policy cooperation. There is a habit of coordination, and a sense of trust and commonality has developed amongst member states. Preferences are shaped through collective, crossborder decision-making processes where member states routinely postpone defining their preferences until they have spoken with their European partners (Sjursen and Rosén 2017, Tonra 2003). ${ }^{4}$

Rather than bargain over the costs and benefits of different courses of action, member states talk themselves into agreement following a consensus-based mode of decisionmaking. This means that in order to gain support from others, they have to convince their European colleagues of the rightfulness of their claims with reference to common norms. They have to present arguments that will be acceptable to others. As for example Howorth has found, "a significant measure of socialisation ensures that the dominant mode of

${ }^{3}$ These findings do not prejudge the question of efficiency, or presume that the EU's global influence is on par with states. They do however rest on an acknowledgement of the EU as a relevant actor at the global scene whose foreign policy affects citizens both within and beyond its borders. For this view, see also Risse 2011.

\footnotetext{
${ }^{4}$ With the Lisbon Treaty, this is also a formal obligation (Article 32).
} 
interaction is consensus-seeking rather than bargaining around fixed national positions" (Howorth 2010, p. 16).

The deliberative perspective, which is premised on the force of reason giving in collective decision-making processes, may help us understand how such processes can contribute to curb power politics as well as particularistic interest claims, and bring policymakers to ground their policies in norms and principles that are commonly accepted. This perspective holds that verbal statements raise expectations of consistency between words and action. Under certain conditions, cognitive dissonance and double standards become problematic (Eriksen 2005, 2009). As a polity that is committed to democratic standards some of the conditions for such a process of reason giving are in place. The core features - that is, the normative ideals of the European Union - are the rights of the human person, democracy and the rule of law. As Mattias Kumm argues: "These values are the bedrock" (Kumm 2005, p. 15). When aiming to talk themselves into consensus, policy-makers are forced to revise, or detract from, positions that are in breach of commonly agreed norms. In their discussions regarding what to do, decision-makers put each other's arguments to the test. They expect their colleagues to be able to justify their position with reference to certain common principles. ${ }^{5}$ Deliberation compels actors to explain and justify their preferences to critical interlocutors and revise them when criticised. As Howorth finds: "If we have a wave of consensus and you are the only obstacle, then you have to have exceptionally good arguments to turn the tide." (Howorth 2010, p. 16).

With the abolition of the pillar structure and the ensuing confirmation in the Treaty of Lisbon of the unity of Union law, the normative basis of the EU foreign policy has been specified and made legally binding: "As a matter of principle, the Lisbon Treaty does not leave any doubt that foreign affairs must respect human rights" (Thym 2011, p. 18, also Cremona 2008). EU foreign policy makers are further obliged to conduct a foreign policy

guided by the principles that have inspired its own creation, development and enlargement, and which it seeks to advance in the wider world: democracy, the rule of law, the universality and indivisibility of human rights and fundamental freedoms, respect for human dignity, the principles of equality and solidarity, and respect for the principles of the United Nations and the Charter of international law (Art. 21 ToL).

The importance that member states attach to this principled dimension to EU foreign policy might be doubted by the unhappy concept of "principled pragmatism" that was introduced in the Global Strategy of the EU (European Union 2016). According to this document, which is to be the navigating chart for EU foreign policy makers, "Principled

\footnotetext{
${ }^{5}$ This is consistent also with the empirical findings of contributors to Thomas (ed.) (2011).Based on a series of 14 case studies, 9 contributors to this edited collection found that in the case that they examined, the common norms that the EU member states have committed to in foreign policy constrained member state choices.
} 
pragmatism will guide our external action in the years to come." (European Union 2016). Natalie Tocci, who was a key figures in the writing of the Strategy, acknowledges that there was resistance to the concept of principled pragmatism amongst member states. They were concerned that the concept of principled pragmatism would bring the Union to abandon the values that had so far informed its foreign policy. However, in her view "This was precisely the opposite of what the intention was" (Tocci 2017, p. 60). ${ }^{6}$

Thus, we may speak of two mutually reinforcing sources of legitimacy at the EU level. The principles enshrined in the Treaties provide a point of reference for EU policy makers in their discussions on what to do. The consensus mode of decision-making in turn enhances the likelihood that the key principles will actually inform decisions on joint foreign policy initiatives. From a deliberative perspective we may expect these two sources of legitimacy to work together to ensure that EU foreign policy not only remains consistent with international law, but also fosters a further strengthening of the cosmopolitan dimension to global legal and institutional arrangements.

A number of case studies of specific decisions or policies find that agreement came about due to appeals to common norms (Pinholt 2004, Riddervold and Sjursen 2012, Romsloe 2004, Sjursen 2003, Sjursen and Rosén 2017, Thomas 2011, Witnes Karlsson 2004). Needless to say, however, there is no guarantee that states will not shift to a bargaining mode when discussing how to proceed, and that policies will thus be the outcome of the will of the most powerful states. ${ }^{7}$ The EU's institutions do not have any possibility to sanction member states if they do not comply with the common norms. Findings across a number of independent studies suggest however that the dominating mode of decisionmaking is by consensus (Christiansen and Vanhoonacker 2008, Duke and Vanhoonacker 2006, Howorth 2010, Juncos and Reynolds 2007, Tonra 2003).

\section{External and internal legitimacy}

Drawing on a deliberative perspective, I have suggested that we may expect the consensus-based mode of decision-making to reinforce the CFSP's treaty based commitment to respect and further strengthen global norms, as they are enshrined in the UN Treaty. In so far as this suggestion is correct, such a mode of decision-making would contribute to strengthen the EU's external legitimacy. Common global norms are designed to ensure that foreign policies take into account the interests and values of third states (as well as their citizens). This is so, as they are mutually binding. Due to the explicit commitment to human rights in the EU's treaties, it is reasonable to assume that the mode of decision-making will also bring forth policies that aim to ensure that the interest of citizens outside of the EU's border are taken into account, and that the EU will

\footnotetext{
${ }^{6}$ To be sure, EU foreign policy often wavers in its support of such values and principles in its external policies (Saltnes 2018).

${ }^{7}$ For the view that EU foreign policy decision-making is subject to the will of the European "great powers," see Gegout (2010), Menon (2013) and Sjursen (2006).
} 
act to strengthen the formal, legal protection of the rights of people and not just of states at the global level. ${ }^{8}$

In sum, we might expect the EU's external legitimacy to be (potentially) stronger than that of the individual member states. When acting on behalf of the EU, they would be bound by the collective norms of the Treaties, which delineate what would be acceptable. At the same time, national executives might have a freer hand in relation to their own citizens. As noted in the first section of this article, the nature of foreign policy does not warrant its exemption from democratic scrutiny. In order for the EU to be able to make a justifiable claim to prevail over the member states, it must be in line with the democratic requirements of autonomy and accountability. It is not enough that the external legitimacy of the EU is enhanced. The deliberative process taking place amongst executives would need to be connected to, and tested in, a broader public debate. And citizens' representatives would need to be able to hold those in power to account (Eriksen 2009, Peters 2005, Zürn 2005). It is only through a process that ensures broad political participation that we can talk of a political order holding democratic legitimacy.

Both with regards to accountability and autonomy, the CFSP falls short. In fact, the way in which the EU's institutions are established, they may contribute to weaken the key attribute of classical parliamentary forms of democratic participation, which is a central element of democratic legitimacy of the EU's member states (Lord 2011). Foreign and security policy is made through interactions and exchanges between the executive branches of the member states. The justifications of foreign policies take place between and among experts belonging to the executive branch of European governments. While there is an open cross-national exchange of views, the process is virtually sealed off from the public. It allows for cross-national critique, and it is reasonable to assume that the critique is informed by the norms enshrined in the EU's Treaties and that these constitute the guidelines for the formulation of EU foreign policy. However, the mechanism that should allow the citizens to have access to and information regarding this exchange are weakened. This is so at the powers of the national parliaments are reduced, without being replaced by sufficiently strong powers at the European level via the European parliament (Rosén 2015). This form of collective, cross-national decision-making is difficult to reconcile with the principle that it should be possible to trace decisions back to a form of authorization by the citizens. Such authorization would probably require institutions and procedures beyond the individual nation states to allow citizens access to information about what goes on amongst the executives and to have an informed opinion.

It is a challenge to identify "who decides". It is often difficult to know, or predict, where responsibility for decisions actually lies. This makes it difficult to disaggregate decisions and trace them back to individual ministers or governments. Key actors are the

\footnotetext{
${ }^{8}$ While norms are not by definition a «good thing» (Sjursen 2006), the argument here is linked to a particular set of norms that have been positivized by the UN Charter, which is signed by the vast majority of states.
} 
representatives of the member states in Brussels, whose autonomy and room for discretion is considerable. Other actors, such as the supranational institutions and NGOs, also in some cases wield influence (Joachim and Dembinski 2011). Yet these actors operate without explicit mandate from the citizens and are not accountable to them. To the extent that accountability plays a part, it is a matter of legal accountability (through national courts) and not accountability to elected representatives (Thym 2011). Certainly, also at the national level, the role of parliaments is often more limited in foreign policy. However, the point here is that the influence of national parliaments is likely to be even further reduced due to policy making within the CFSP.

Given that developments so far are the result mainly of informal practice, however, it is difficult to establish procedures that may compensate for their effects on citizens' status as authors of the policies. Also, there is a sense of contingency or haphazardness about which issues are brought outside the intergovernmental mode of decision making, which makes it difficult to ensure proper channels and mechanisms of authorization (Sjursen and Rosén 2017).

As it is difficult to find out where decisions are actually made, it is also unclear who should be accountable. The EP has, through active pressure, gradually extended its influence (Barbed 2004, Crum 2006, Maurer, Kietz \& Völkel 2005, Rosén 2015). The general rule is, however, that it is only consulted on the main aspects and basic choices made in the field of foreign and security policy and is kept informed of how those policies evolve. With the establishment of the EEAS, it has succeeded in strengthening its position a little further, as the High Representative is subject to Parliamentary questioning on the same basis as the Commissioners. Further, its role in deciding on the budget of the EEAS is important. Finally, the EP's active involvement in the discussion on the entire set-up of the EEAS suggests that it may with time become a more influential actor. However, it is widely acknowledged that it neither authorises decisions, nor is able to hold those that make decisions accountable (Crum 2006, Peters et al. 2008). Moreover, the powers of national parliaments are limited due to these very departures from the core premises of intergovernmentalism. The actual severeness of this condition might be somehow more limited, as most Euro barometer polls show that there is support amongst European citizens for a common European foreign and security policy (Peters 2014). However, from a normative perspective, this does not on its own suffice as a legitimacy basis for foreign policy. ${ }^{9}$

In sum, EU foreign policy making, while enhancing deliberation, is vulnerable to the critique often made against the more pragmatic versions of deliberative democracy, which is that they do not sit well with "...the emphasis on political equality and broad political participation often also inherent in concept of transnational democracy." (Peters 2005, p. 112)

${ }^{9}$ For further discussion on the link between public opinion and democracy in foreign policy, see Peters (2014). 


\section{Conclusion}

The aim of this article has been to discuss on what basis the institutions of the EU would be able to make a reasonable claim to prevail over the member states in foreign and security policy, as well is how the EU could make a legitimate claim to be listened to by third parties. The starting point for this argument was the suggestion that legitimacy is not only important in itself, it is also important in order to ensure a stable system of foreign policy. In order to discuss the above question, I started out by specifying what might be adequate criteria for assessing the legitimacy of EU foreign policy. Subsequently, I analyzed the main features of the system of foreign policy decisionmaking in light of these criteria. Drawing on a concept of deliberation, I found that we may expect the external legitimacy of EU foreign policy to be enhanced compared to those of the member states taken separately. This is due to the consensus-based mode of decision-making, which is considered to prevail within the CFSP. From a deliberative perspective, we would expect it to work to reinforce the likelihood of compliance with global (cosmopolitan) norms, as they are enshrined in the UN Declaration, in the EU's foreign policy initiatives. Thus, it would contribute to ensure that the EU conducts a foreign policy that at least to some extent takes into account the interests and values of third states and their citizens, rather than conduct a foreign policy that merely serves particular European interests.

Paradoxically, while we would expect the consensus mode to enhance the external legitimacy of EU foreign policy, there is a risk at the same time that it would weaken its internal - democratic - legitimacy. Experts working in the executive branches of European states make foreign policy decisions collectively. The elected representatives of citizens have only very limited access to information about the process, and thus also about the reasons behind the policies that are developed. This makes it very difficult for them to form an independent opinion of what ought to be done, as well as to hold those in power responsible.

The unsettled legitimacy basis of EU foreign policy testifies to the fragility of the political order of the EU's foreign policy. It is true that citizens appear to have been happy to leave foreign and security policy to the executives, perhaps assuming that they possess the required knowledge to act in the best interest of all. Foreign and security policy is seen mainly as an issue that interests the elites and is only occasionally subject to great controversy. However, as long as citizens and parliaments have not been asked, it cannot be more than an uncorroborated assumption that they are willing to blindly put responsibility for foreign policy in the hands of the executive. What is more, As the EU moves forward with new initiatives of enhanced cooperation in foreign and security policy it is likely to become more difficult to maintain the already uneasy balance between the advantages of joint decision-making across European states and the costs this incurs with regard to democratic legitimacy. 


\section{References}

Allen, D. (1998). Who speaks for Europe? The Search for an Effective and Coherent External Policy. In J. Peterson and H. Sjursen (Eds.), A Common Foreign Policy for Europe?, London: Routledge, pp. 41-58.

Barbé, E. (2004). The Evolution of CFSP Institutions: Where does Democratic Accountability Stand? The International Spectator, 39(2), 47-60.

Bicchi, F. (2011) The EU as a community of practice: foreign policy communications in the COREU network. Journal of European Public Policy, 18,8:1115-1132.

Christiansen, T. \& Vanhoonacker, S. (2008). At a Critical Juncture? Change and Continuity in the Institutional Development of the Council Secretariat. West European Politics, 31(4), 751-70.

Cremona, M. (2008). Coherence through Law: What Difference will the Treaty of Lisbon Make? Hamburg Review of Social Sciences, 3(1), 11-36.

Crum, B. (2006). Parliamentarization of the CFSP through Informal Institution-making? The Fifth European parliament and the EU High Representative. Journal of European Public Policy, 13(3), 383-401.

Dahl, R. A. (1989). Democracy and Its Critics. New Haven, CT: Yale University Press.

Dworkin, R. (1986) Laws Empire, Cambridge, MA, Harvard Univeristy Press.

Duke, S. \& Vanhoonacker, S. (2006). Administrative Governance and CFSP. In H. C. H. Hofmann \& A. H. Türk (Eds.), EU Administrative Governance. Cheltenham: Edward Elgar, pp. 361-87.

Eriksen, E.O. (Ed.) (2005) Making the European Polity: Reflexive integration in the EU. London: Routledge.

Eriksen, E. O. (2009). The Unfinished Democratization of Europe. Oxford: Oxford University Press.

European Union (2016) Shared Vision, Common Action: A Stronger Europe Europe. A Global Strategy for the European Union's Foreign and Security Policy. https://europa.eu/globalstrategy/sites/globalstrategy/files/regions/files/eugs_revi ew_web_0.pdf

Gegout, C. (2010) European Foreign and Security Policy: States, Power, Institutions, and American Hegemony. Toronto: University of Toronto Press

Habermas, J. (1996). Between Facts and Norms. Cambridge, MA: MIT Press.

Hoffmann, S. (1966) 'Obstinate or Obsolete? The Fate of the Nation-State and the Case of Western Europe', Daedalus, 95, (3): 862-915

Howorth, J. (2010). The Political and Security Committee: A Case Study in Supranational Inter-Governmentalism. Les Cahiers europeens de Sciences Po, No. 01/2010.

Hyde-Price, A. (2006) '"Normative" power Europe: a realist critique', Journal of European Public Policy, 13(2): 217-34.

Joachim, J. and Dembinski, M. (2011) A contradiction in terms? NGOs, democracy, and European foreign and security policy. Journal of European Public Policy, 18 (8): 1151- 1168. 
Juncos, A.E. and Pomorska, K. (2011) Invisible and Unaccountable? National Representatives and council Officials in EU foreign policy. Journal of European Public Policy, 18, 8: 1096-1114.

Juncos, A. E. \& Reynolds, C. (2007). The Political and Security Committee: Governing in the Shadow. European Foreign Affairs Review, 12, 127-47.

Kumm, M. (2005). To be a European Citizen: Constitutional Patriotism and the Treaty Establishing a Constitution for Europe. In E.O. Eriksen et al (Eds.), The European Constitution: The Rubicon Crossed? ARENA Report No 03/0. Oslo: ARENA, pp. 7-63.

Lord, C. (2011) The political theory and practice of parliamentary participation in the Common Security and Defence Policy, Journal of European Public Policy, 18, 8: 1133- 1150.

Maurer, A., Kietz, D. \& Völkel, C. (2005). Interinstitutional Agreements in the CFSP: Parliamentarization through the Back Door? European Foreign Affairs Review, 10, 175-95.

Menon, A. (2013) "Defence Policy and the logic of High Politics" in P. Genschel and M. Jachtenfuchs (eds) Beyond the Regulatory Policy? The European integration of core state powers. Oxford: Oxford Univeristy Press: 67-85.

Neyer, J. (2012) The Justification of Europe. A Political Theory of Supranational Integration. Oxford: Oxford University Press.

Peters, B. (2005). Public discourse, identity and the problem of democratic legitimacy. In E.O. Eriksen, (Ed.) Making the European Polity: Reflexive integration in the EU. London: Routledge, pp. 84-123.

Peters, D. (2014) "European Security Policy for the People? Public Opinion and the EU's Common Foreign, Security and Defence Policy," European Security, 23: 4: 388-408.

Peters, D., Wagner, W and Deitelhoff, N. (2008). "Parliaments and Security Policy: Mapping the Parliamentary Field". In D. Peters, W. Wagner and N. Deitelhoff (eds). The Parliamentary Control of European Security Policy. ARENA report 7/08. Oslo: ARENA, pp. 3-28.

Pettit, P. (1997) Republicanism: A Theory of Freedom and Government, Oxford, Oxford University Press.

Pinholt, K. (2004) Influence through arguments? A study of the Commission's influence on the climate change negotiations. ARENA Report 03/2004.

Rawls, J. (1993). Political Liberalism. New York, NY: Columbia University Press.

Riddervold, M. \& Sjursen H. (2012). Playing Into the Hands of the Commission? Accounting for the Impact of International Organisations on EU Foreign Policy. In C. Oriol \& K.E. Jørgensen (Eds.) When multilateralism hits Brussels. Basingstoke, Palgrave: 42-57.

Risse, T. (2011) 'Norms and all that: Progress in research on EU Foreign Policy' in D. Thomas (ed) Making EU Foreign Policy. National Preferences, European Norms and Common Policies, Basingstoke, Palgrave: 192-202.

Rosén, G. (2015). Striving for Influence: The European Parliament in EU Foreign Policy. ARENA Report no. 2/15. Oslo: ARENA. 
Romsloe, B. (2004) Mellom makt og argumentasjon. En analyse av småstater i EUs felles utenriks- og sikkerhetspolitikk. ARENA Report 02/2004.

Saltnes, J. (2018) The European Union's Human Rights Policy: Is the EU's Use of the Human Rights Clause Inconsistent?, Global Affairs, doi: 10.1080/ 23340460.2018.1535251

Sen, A. (2010) The idea of justice, London: Penguin.

Scharpf, F. (1999) Governing in Europe: Effective and Democratic. Oxford: Oxford University Press.

Schmidt, V. (2013) 'Democracy and Legitimacy in the European Union Revisited: Input, Output and Throughput', Political Studies, 61(1): 2-22.

Sjursen, H. (2003). Understanding the Common Foreign and Security Policy: Analytical Building Blocs. In M. Knodt \& S. Princen (Eds.), Understanding the European Union's External Relations, London: Routledge, pp. 35-53.

Sjursen, H. (2006). 'The EU as a 'Normative Power": How Can This Be?', Journal of European Public Policy, 13(2): 235-251.

Sjursen, H. (2011). Not so intergovernmental after all? On democracy and integration in European Foreign Policy. Journal of European Public Policy, 18(8), 1078-95.

Sjursen, H. and Rosén, G. (2017) Arguing Sanctions: On the EU's Response to the Crisis in Ukraine. Journal of Common Market Studies. 55,1: 20-36.

Smith, M. E. (2004). Europe's Foreign and Security Policy: The Institutionalization of Cooperation. Cambridge: Cambridge University Press.

Strikwerda, J. (2016) Sovereignty at Stake? The European Commission's proposal for a Defence and Security Procurement Directive. European Security. 26(1): 19- 36.

Thomas, D. (ed) (2011) Making EU Foreign Policy. National Preferences, European Norms and Common Policies, Basingstoke, Palgrave.

Thym, D. (2006) "Beyond parliaments reach? The role of the European Parliament in the CFSP" European Foreign Affairs Review 11: 109-27.

Thym, D. (2011). Holding Europe's CFSP/CSDP executive to account in the age of the Lisbon Treaty. CEU Ediciones, Documento de Trabajo, Serie Unión Europea, 53.

Tocci, N. (2017) Framing the EU Global Strategy. A Stronger Europe in a Fragile World. Cham, Palgrave Macmillan.

Tonra, B. (2003). Constructing the Common Foreign and Security Policy: The Utility of a Cognitive Approach. Journal of Common Market Studies, 42(4), 731-756.

Treaty of Lisbon. http://www.lisbon-treaty.org/wcm/the-lisbon-treaty.html

Vanhoonacker, S., Dijkstra, H. \& Maurer, H. (2010). Understanding the Role of Bureaucracy in the European Security and Defence Policy: The State of the Art. In Vanhoonacker, S., H. Dijkstra and H. Maurer (eds). Understanding the Role of Bureaucracy in the European Security and Defence Policy, European Integration online Papers, 14(1), http://eiop.or.at/eiop/texte/2010-004a.htm.

Weiler, J. (1999). The Constitution of Europe, "Do the New Clothes have an Emperor" and Other Essays on European Integration. Cambridge: Cambridge University Press.

Witnes Karlsson, V. (2004). EU - en normativ internasjonal aktør? En analyse av Russland i EUs utenrikspolitikk, ARENA Report, 5. 
Zürn, M. (2005). Global Governance and Communicative Action. In D. Held \& M. Koenig-Archibugi (Eds.), Global Governance and Public Accountability. Oxford: Blackwell Publishing, pp. 136-63. 